УДК 330.341 .1

DOI: https://doi.org/10.37320/2415-3583/8.11

Шушкова Ю.В.

кандидат економічних наук, доцент, доцент кафедри фінансового менеджменту,

Львівський національний університет імені Івана Франка

\title{
АНАЛІЗ ЕФЕКТИВНОСТІ ДЕРЖАВНОЇ ПОЛІТИКИ ПІДТРИМКИ ТА СТИМУЛЮВАННЯ ТЕХНОЛОГІЧНИХ РЕФОРМ В УКРАЇНІ
}

\begin{abstract}
У статті наведено результати аналізування ефективності державної політики підтримки та стимулювання розвитку технологічних реформ в Україні. Встановлено, щзо в Україні не виконуються базові завдання державної політики технологічної модернізачії. Щодо завдання організації та управління, то відсутні иентральний орган та місцеві структури, які забезпечують формування та реалізацію державної політики. Щодо завдання планування, то несформованою є система стратегічного планування технологічної модернізачії економіки, відсутніми є конкретні інструменти та механізми регулювання. Щодо завдання формування правого поля, то актуалізувалась необхідність перегляду положень базових нормативно-правових актів, які регламентують інновачійно-технологічну діяльність, зокрема щьоо підсилення ефективних інструментів стимулювання та підтримки розвитку інновачійно-технологічної діяльності. Щодо завдання становлення інфраструктури, то низьким є рівень розвитку, а слабкою - інституиійна спроможність елементів інфраструктури підтримки й стимулювання розвитку процесів технологічної модернізачії начіональної економіки. Щодо завдання забезпечення мотивачїі, то слабкою залишається спроможність системи фінансово-кредитного сприяння технологічному розвитку економіки.
\end{abstract}

Ключові слова: технологічна модернізачія, функиії та завдання, державна інноваційно-технологічна політика.

Постановка проблеми. В процесі аналізування державної політики забезпечення технологічних реформ потрібно не лише дати відповідь на питання її ефективності, але й оцінити діяльність владних структур щодо формування передумов реалізації технологічних змін і зрушень. Серед таких умов одними 3 найбільш засадничих є стан розвитку промисловості загалом, а також усіх, без винятку, іiї галузей, міра цифровізації економіки, якість функціонування сектору інформаційнокомунікаційних технологій та впровадження його результатів (зокрема, сучасних передових і прогресивних інформаційних технологій) у базових видах економічної діяльності. Саме якісна взаємодія процесів структурно збалансованого розвитку промисловості та створення сектором ІКТ i впровадження у реальний сектор економіки прогресивних технологій дають підстави дійти висновку про рівень технологічної модернізації в системі реіндустріалізації національного господарства України.

Аналіз останніх досліджень i публікацій. Вивченню теоретико-методичних засад інноваційної діяльності в контексті формування передумов забезпечення конкурентних позицій національної економіки присвячені праці Т. Васильціва, О. Овечкіна, К. Іванова, Т. Скрипко, А. Мельник, А. Васіна та інших науковців. Над дослідженням функціонально-структурних характеристик технологічної модернізації національного господарства працювали Л. Федулова, К. Бужимська, А. Вешко, М. Бузмакова, Т. Мірзодаєва та інші вчені. Проте питання аналізування ефективності державної політики забезпечення технологічної модернізації економіки актуальне завжди, оскільки постійно змінюється ситуація в інноваційно-технологічній сфері країни, непостійними $\epsilon$ чинники та умови інноваційно-технологічної діяльності. Отже, аналіз ефективності державної політики на поточному етапі розвитку дає свіжий грунт думок та аргументів на користь її вдосконалення та підвищення ефективності.

Мета статті полягає в аналізуванні ефективності державної політики підтримки та стимулювання розвитку технологічних реформ в Україні.

Виклад основного матеріалу. Досить наглядними критеріями якості та ефективності державної політики забезпечення інноваційно-технологічного розвитку є частки вітчизняних інноваційних та високотехнологічних товарів (послуг) на світовому ринку та в структурі національного експорту. 3 огляду на це можна говорити про недоліки в системі державної політики стимулювання технологічної модернізації національного господарства України, адже частка високотехнологічного експорту в структурі промислового експорту у 2018 р. становила лише 5,4\%, а за 2015-2018 pр. мала лише низхідну динаміку, що $є$ негативним, а також свідчить про погіршення можливостей вітчизняної економіки для іiї технологічної модернізації (табл. 1).

Найвище значення високотехнологічного експорту України припадало на 2015 р. (8,5%), але й такий рівень не може характеризуватися як серед- 
Таблиця 1 - Співвідношення високотехнологічного експорту у структурі промислового експорту України та інших країн у 2005, 2010-2018 рр., \%

\begin{tabular}{|l|c|c|c|c|c|c|c|c|c|c|c|}
\hline \multirow{2}{*}{ Країна } & \multicolumn{10}{|c|}{ Роки } \\
\cline { 2 - 13 } & $\mathbf{2 0 1 0}$ & $\mathbf{2 0 1 1}$ & $\mathbf{2 0 1 2}$ & $\mathbf{2 0 1 3}$ & $\mathbf{2 0 1 4}$ & $\mathbf{2 0 1 5}$ & $\mathbf{2 0 1 6}$ & $\mathbf{2 0 1 7}$ & $\mathbf{2 0 1 8}$ & $\mathbf{2 0 1 8 / 2 0 0 5}$ рp. & $\mathbf{2 0 1 8 / 2 0 1 7} \mathbf{p p . ~}$ \\
\hline Україна & 4,3 & 4,9 & 6,9 & 6,7 & 7,5 & 8,5 & 7,2 & 6,3 & 5,4 & $+1,1$ & $-0,9$ \\
\hline Світ & 20,6 & 18,7 & 19,0 & 19,1 & 19,1 & 20,0 & 20,0 & 21,6 & 17,9 & $-2,7$ & $-3,7$ \\
\hline СС & 17,0 & 16,3 & 17,0 & 17,1 & 17,2 & 17,8 & 18,0 & 16,4 & 15,9 & $-1,1$ & $-0,5$ \\
\hline $\begin{array}{l}\text { зокрема, } \\
\text { Польща }\end{array}$ & 7,7 & 6,6 & 7,9 & 8,8 & 10,2 & 11,0 & 11,0 & 10,9 & 10,6 & $+2,9$ & $-0,3$ \\
\hline $\begin{array}{l}\text { Чеська } \\
\text { Республіка }\end{array}$ & 17,9 & 18,7 & 18,6 & 17,3 & 17,4 & 17,8 & 16,9 & 17,9 & 19,6 & $+1,7$ & $+1,7$ \\
\hline Естонія & 15,7 & 22,2 & 20,5 & 20,5 & 23,3 & 22,4 & 22,0 & 17,6 & 16,8 & $+1,1$ & $-0,8$ \\
\hline Угорщина & 25,9 & 25,2 & 21,2 & 19,4 & 16,7 & 17,2 & 17,5 & 17,3 & 16,9 & -9 & $-0,4$ \\
\hline Латвія & 11,3 & 10,6 & 11,0 & 11,0 & 11,1 & 12,8 & 12,7 & 12,6 & 12,1 & $+0,8$ & $-0,5$ \\
\hline Литва & 6,2 & 10,6 & 10,2 & 10,4 & 10,3 & 10,1 & 11,9 & 11,7 & 11,7 & $+5,5$ & - \\
\hline Румунія & 12,5 & 11,6 & 8,1 & 7,4 & 8,4 & 9,4 & 10,4 & 9,8 & 10,1 & $-2,4$ & $+0,3$ \\
\hline Словаччина & 7,1 & 7,4 & 9,6 & 11,0 & 11,1 & 11,2 & 10,7 & 11,8 & 10,6 & $+3,5$ & $-1,2$ \\
\hline $\begin{array}{l}\text { Російська } \\
\text { Федерація }\end{array}$ & 9,6 & 8,5 & 9,2 & 10,7 & 12,1 & 16,4 & 10,1 & 11,6 & 10,9 & $+1,3$ & $-0,7$ \\
\hline Білорусь & 3,0 & 2,5 & 2,9 & 4,5 & 4,1 & 4,4 & 4,8 & 4,3 & 3,9 & $+0,9$ & $-0,4$ \\
\hline Молдова & 9,7 & 7,4 & 5,1 & 2,7 & 5,3 & 4,6 & 3,4 & 5,3 & 2,5 & $-7,2$ & $-2,8$ \\
\hline
\end{tabular}

Джерело: [11]

ній чи високий. Наприклад, у 2018 р. середньосвітове значення цього показника становило $17,9 \%$ (на 12,5 в. п. більше, ніж для України).

Середне значення високотехнологічного експорту для країн ЄС у 2018 р. становило 15,9\% і було на 10,5 в. п. вищим, ніж для України. Більше того, у більшості країн $Є С$, що є сусідами нашої країни, за 2010-2018 рр. частка високотехнологічного експорту в структурі промислового експорту підвищувалася, а саме у Польщі вона зросла на 2,9 в. п., у Чеській Республіці - на 1,7 в. п., в Естонії - на 1,1 в. п., в Латвії - на 0,8 в. П., у Литві на 5,5 в. П., у Словаччині - на 3,5 в. п. В України також відбулося підвищення (на 1,1в. п.), але воно було незначним та суттєво не вплинуло на співвідношення технологічності експорту.

Таким чином, низькі позиції України в рейтингах конкурентоспроможності, інноваційно-технологічного розвитку, цифровізації тощо є підтвердженням того, що вітчизняна політика в цій сфері або відсутня, або недостатня, або низько ефективна. Додатковими аргументами на користь такого висновку $є$ виконання або, навпаки, недовиконання базових завдань державної політики, до яких передусім належать організація та управління, планування, формування нормативно-правового поля, будування інституційної інфраструктури, стимулювання.

Відомо, що для реалізації державної політики в тій чи іншій сфері у структурі державного апарату управління має бути наявним орган, який відповідальний за іiі планування та втілення у життя. Технологічна модернізація економіки не $\epsilon$ винятком, оскільки завдання інноваційно-техно- логічного розвитку, створення та впровадження інновацій, розвитку економіки та суспільства на інноваційних засадах практично у всі роки незалежності країни були серед пріоритетних.

На вищих щаблях державної влади було розуміння, що має бути структура, відповідальна за розвиток цих процесів. Згідно із Законом України «Про інноваційну діяльність» ними є Верховна Рада України, Рада АР Крим та органи місцевого самоврядування, Кабінет Міністрів України, центральний орган виконавчої влади, що забезпечує та реалізує державну політику у сфері науковотехнічної та інноваційної діяльності, інші центральні органи виконавчої влади.

В різні часи в країні були різні центральні органи виконавчої влади, відповідальні за формування та реалізацію державної інноваційно-технологічної політики. Назви органів змінювалися частіше, ніж приймалися стратегічні управлінські рішення в цій сфері, жодній з цих структур не вдалося гарантувати високу ефективність політики та істотні системні зрушення, а також забезпечити показники інноваційно-технологічного розвитку національної економіки.

Проте сьогодні в країні відсутній центральний орган виконавчої влади, що забезпечує формування та реалізує державну політику у сфеpax наукової, науково-технічної та інноваційної діяльності, трансферу технологій, адже з вересня 2019 р. ці та інші (зокрема, розвиток сектору цифровізації) функції та завдання об'єднані в Міністерстві цифрової трансформації України (Мінцифра). У підсумку еволюційного злиття структур, відповідальних за інноваційний роз- 
виток та інформатизацію, утворився орган, який тепер відповідальний лише за цифровізацію. Слід зауважити, що в структурі Міністерства розвитку економіки, торгівлі та сільського господарства України також відсутній департамент, який би спеціалізувався на питаннях інноваційно-технологічного розвитку економіки.

3 огляду на наведене вище нині в Україні відповідальність за інноваційно-технологічний розвиток у системі найвищих органів влади покладена лише на Міністерство освіти і науки України, а єдиним органом тут $є$ Директорат інновацій та трансферу технологій МОН України, утворений у 2017 р. Головними завданнями діяльності Директорату $\epsilon$ ініціювання пропозицій та розроблення документів державної політики, проєктів актів законодавства, що забезпечують модернізацію та ефективне функціонування сфери інновацій та трансферу технологій, оцінювання результатів реалізації державної політики в цій сфері.

Організаційно-управлінські структури, які б мали формувати та впроваджувати державну політику інноваційно-технологічного розвитку економіки, відсутні на регіональному та місцевому рівнях, що є негативним явищем. Відповідно, ці питання віддані на «відкуп» обласним та районним державним адміністраціям, які через обмеженість фінансового та організаційного ресурсу не в змозі повністю регулювати означені процеси та, відповідно, де-інде, в межах стратегій чи окремих програм регіонального розвитку, вживають окремих мало дієвих, часто не пов’язаних між собою заходів.

Іншим надважливим завданням $€$ планування державної політики, що також має вади й недоліки. Так, чинна сьогодні Стратегія розвитку сфери інноваційної діяльності на період до 2030 р. має низку системних вад. По-перше, це відсутність будування його положень на фундаменті технологічної модернізації економіки або принаймні на грунті інноваційно-технологічного розвитку. Йдеться про те, що сьогодні, в епоху глобалізації та діджиталізації, все більшого значення набувають саме технологічні інновації або прогресивні передові технології. Вся сфера цифрової економіки - це інформаційні технології. Значно меншої важливості (порівняно 3 технологічними нововведеннями) набувають товарні, організаційні, маркетингові, управлінські та інші види інновацій, тому акцентування уваги на розвитку інноваційної діяльності лише консервує відставання економіки України від країн, що є інноваційно-технологічними лідерами.

По-друге, це відсутність у Стратегії конкретних інструментів та механізмів, зі впровадженням яких будуть вирішені визначені в документі проблеми.
По-третє, шляхи державної політики, які пропонуються в цьому програмному документі, орієнтовані на вирішення проблем, тоді як більш прогресивний підхід стосується як усунення перешкод інноваційно-технологічного розвитку (вирішення проблем), так і досягнення стратегічних цілей чи завдань державної політики, які в Стратегії не визначені.

По-четверте, Стратегією чи іншим нормативно-правовим актом України не закріплено чітко визначені конкретні джерела та обсяги фінансово-ресурсного забезпечення вжиття планових заходів. За такого підходу цей стратегічний плановий документ, як і практично всі інші, які приймалися до цього, не буде достатньою мірою профінансований, отже, реалізований.

По-п'яте, Стратегією передбачені конкретні кількісні показники, а саме результати їі реалізації, яких буде досягнуто за 2019-2030 pр., але прогнозні значення показників жодним чином не обгрунтовані, що ставить під сумнів вибір їх орієнтирами державної політики, а також не показано очікуваний вплив реалізації Стратегії на розвиток економіки загалом.

По-шосте, у Стратегії відсутні чіткі інструменти фінансово-податкового стимулювання інноваційно-технологічно активних підприємств, а також створення, розвитку й ефективного функціонування елементів інноваційно-технологічної інфраструктури (інноваційних парків, інноваційно-технологічних кластерів, венчурних фондів, техніко-впроваджувальних промислових зон).

Потрібно зазначити, що в Україні вже неодноразово приймалась низка стратегічних планових документів із розвитку інноваційно-технологічної діяльності. Протягом 2013-2019 рр. схвалено понад 40 стратегічних планових документів галузевого рівня, які стосуються інноваційно-технологічного розвитку. Проте цільові орієнтири більшості цих стратегій, програм, концепцій так і не реалізовані, що є свідченням наявності окремих помилок, припущених під час планування, відсутності системності планових заходів, наявності низки зовнішніх суб'єктивних перешкод (відсутність політичної волі, брак бюджетно-фінансового ресурсу, бюрократизм та корупція в органах виконавчої влади).

Відомо, що найкращий спосіб досягнення успіху в тій чи іншій царині державного управління передбачає створення сприятливого середовища, в якому економічні агенти будуть мотивованими до раціональної поведінки, відповідно, всі процеси розвиватимуться в необхідному напрямі. Таке середовище передусім визначається законодавством країни. Саме тому третє завдання державної політики забезпечення технологічної модернізації економіки стосується формування відповідного нормативно-правового поля. 
Загалом нормативно-правове поле щодо врегулювання господарської діяльності, а також відносин, пов'язаних 3 науковою, науководослідною, науково-технічною, інноваційнотехнологічною діяльністю, їх інвестиційним забезпеченням, в Україні сформоване, що $є$ позитивним явищем. Водночас є підстави говорити про окремі недоліки.

По-перше, в Україні наявні базові закони в аналізованій сфері. Це, зокрема, Закони України «Про наукову i науково-технічну діяльність», «Про інноваційну діяльність», «Про інвестиційну діяльність». Вони справді закладають правовий фундамент розвитку інноваційно-технологічної діяльності в країні. Однак ці НПА були прийняті достатньо давно. Попри те, що в їх положення щорічно вносяться ті чи інші зміни, визріла необхідність їх істотного перегляду, включаючи розроблення та прийняття єдиного закону про технологічну модернізацію економіки України та іiі фінансово-ресурсне забезпечення. За такої умови саме технологічна модернізація була б визначена стратегічним імперативом державної політики, а всі заходи та засоби в межах науково-технічної, інноваційної, технологічної та іншої діяльності підпорядковувалися б досягненню генеральної мети та спрямовувалися б на них.

По-друге, в Україні бракує законодавчих актів, які стосувалися б регламентування діяльності найбільш ефективних інструментів стимулювання та підтримки розвитку інноваційно-технологічної діяльності. Йдеться, наприклад, про діяльність венчурних фондів або інноваційних парків, тобто право на існування таких структур у країні сформоване, але не передбачені чітко визначені інструменти їх спеціального (зокрема, пільгового) режиму функціонування, фінансової підтримки, податкових стимулів, спеціального кредитування, контролю за реалізацією інноваційно-технологічних проектів та їх результатів; недостатньо визначеними залишаються окремі важливі терміни й поняття, зокрема найновіші.

По-третє, потребує законодавчих змін система державного фінансування наукової, науково-технічної та інноваційної діяльності. Значні суми коштів виділяються в Україні на науково-дослідну діяльність закладів освіти, передусім вищої освіти, а також діяльність структур Національної академії наук України, інших відомчих науководослідних організацій. У підсумку виконання таких робіт щорічно здаються сотні звітів про виконання НДР, результати яких жодним чином не впроваджуються; не ведеться моніторинг реалізації результатів досліджень; не здійснюється оцінювання ефективності витрачених бюджетних коштів тощо.

Щодо формування сприятливого для технологічної модернізації економіки середовища постає четверте завдання державної політики в цій сфері. Ним є будування повноцінної та якісної інституційної інфраструктури інноваційно-технологічної діяльності.

Як зазначається у Стратегії розвитку сфери інноваційної діяльності на період до 2030 р., нині в Україні здійснюють діяльність 40 індустріальних парків, 26 наукових парків, 16 технопарків, 24 центри інновацій та технологічного трансферу тощо, що наче є свідченням достатнього рівня розвитку інноваційно-технологічної інфраструктури. Однак при цьому інтернет-сторінки більшості цих структур неактуальні, інформація про їх діяльність відсутня, практично всі центри інновацій та технологічного трансферту в регіонах України припинили свою діяльність. За більш як 10 років (2006-2018 рр.) у нашій країні було зареєстровано лише 16 інноваційних проєктів (в середньому дещо більше одного на рік), в цей період не було жодного проєкту, зареєстрованого технологічними парками, а 32012 р. не виділялися бюджетні кошти на фінансування розвитку інноваційної інфраструктури. Зазначене є свідченням низького рівня розвитку та інституційної слабкості елементів інфраструктури, відповідальних за підтримку та стимулювання розвитку процесів технологічної модернізації національної економіки, що критично негативно, адже інноваційно-технологічна інфраструктура - це один з базисних елементів середовища розвитку інноваційної діяльності та впровадження сучасних технологій у країнах інноваційно-технологічних лідерах у світі.

Ще одним не менш важливим завданням державної політики, зокрема у сфері технологічної модернізації економіки, є стимулювання. Фактично йдеться про механізми та інструменти економічного характеру, упровадження яких підсилює мотивацію економічних агентів до планування, організації та безпосереднього провадження інноваційної діяльності, створення, залучення й використання передових технологій. Натомість це завдання в Україні належним чином не реалізується. В країні практично відсутні будь-які переваги для інноваційно та технологічно активних суб'єктів господарювання порівняно $з$ іншими підприємствами та організаціями, зокрема, тими, які займаються примітивними формами перепродажу товарів чи виробництвом та збутом сировини, продукції з низьким рівнем доданої вартості, тоді як інноваційно-технологічна діяльність високо ризикова, потребує значних обсягів інвестування, часто має довгі строки окупності тощо.

Відсутні інструменти фінансово-кредитного сприяння (знижені ставки за відсотками банків, відшкодування підприємствам частини тіла кредиту, пролонгування строків кредитування, надання поручительства тощо) інноваційно-тех- 
нологічної діяльності, податкові стимули для діяльності інвестиційних парків, спеціальні режими функціонування венчурних фондів.

Не зорієнтовані на стимулювання інноваційнотехнологічної діяльності також суб'єкти вітчизняного фінансово-кредитного, зокрема банківського, сектору. Відсоткова ставка за кредитами в Україні залишається надмірно високою, строки кредитування - малими, а умови оформлення майнового забезпечення та проходження процедур оформлення кредиту - складними й тривалими. Отже, банківські кредити під реалізацію інноваційно-технологічних проєктів вітчизняними підприємствами практично не залучаються. До негативних аспектів, які потребують державного регулювання, можна віднести також зменшення кількості діючих банків, зниження рівня банківського кредитування до ВВП країни, малі обсяги та скорочення темпів збільшення банківського кредитування реального сектору економіки.

Узагальнення визначених недоліків державної політики забезпечення технологічної модернізації економіки України наведене на рис. 1.

Визначені недоліки державного регулювання процесів технологічної модернізації економіки України потребують свого усунення під час формування та реалізації більш якісної та ефективної державної політики в цій сфері.

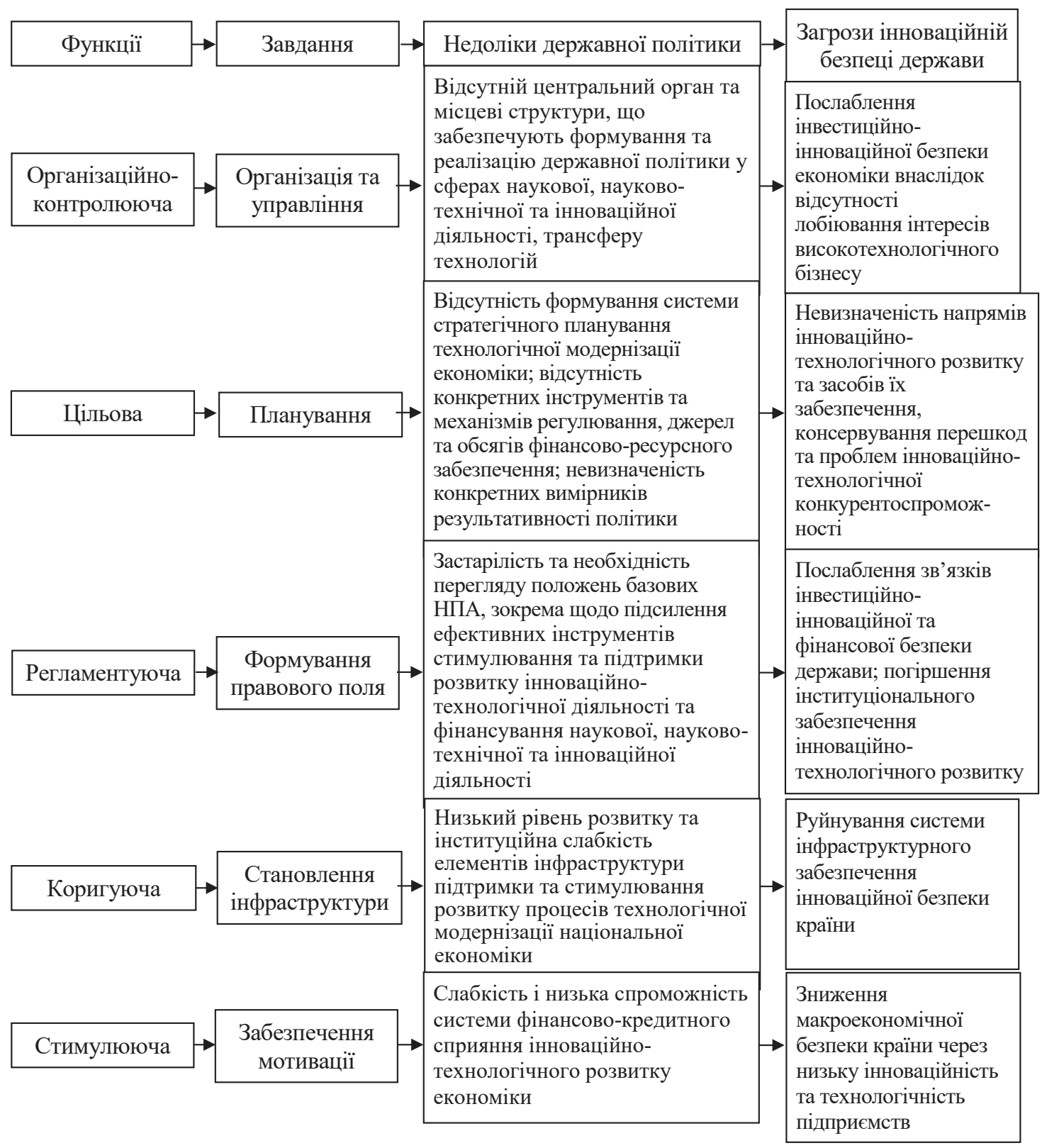

Рисунок 1 - Недоліки державної політики технологічної модернізації економіки України за функціями та завданнями управління 
Висновки. В разі невиконання базисних функцій і завдань державна політика об'єктивно неефективна. Саме такі висновки випливають у підсумку аналізування державної політики забезпечення технологічної модернізації економіки України, оскільки основоположні функції та завдання тут нереалізовані. Підтвердженням зазначеного $є$ те, що в Україні відсутній центральний орган та місцеві структури, які забезпечують формування та реалізацію державної політики у сферах наукової, науково-технічної та інноваційної діяльності, трансферу технологій (недоліки в системі організації та управління), несформованою залишається система стратегічного планування технологічної модернізації економіки, відсутніми - конкретні інструменти та механізми регулювання, джерела та обсяги фінансово-ресурсного забезпечення, невизначеними - чіткі вимірники результативності регу- лювання (вади планування державної політики), актуалізувалась необхідність перегляду положень базових нормативно-правових актів, які регламентують інноваційно-технологічну діяльність, зокрема щодо підсилення ефективних інструментів стимулювання та підтримки розвитку інноваційнотехнологічної діяльності, фінансування наукової, науково-технічної та інноваційної діяльності (недоліки нормативно-правового поля), низьким є рівень розвитку, а слабкою $є$ інституційна спроможність елементів інфраструктури підтримки й стимулювання розвитку процесів технологічної модернізації національної економіки (відсутність формування інституційної інфраструктури), слабкою залишається спроможність системи фінансово-кредитного сприяння інноваційно-технологічного розвитку економіки (відсутність реальних стимулів до активізації інноваційно-технологічної діяльності).

\section{Список використаних джерел:}

1. Васильців Т., Магас Н. Передумови конкурентоспроможності підприємств роздрібної торгівлі. Науковий вісник НЛТУ Украӥни. 2014. Вип. 24.2. С. 218-222.

2. Овєчкіна О., Іванова К. Огляд методів оцінки рівня інноваційного потенціалу економічних суб'єктів. Економічний вісник Донбасу. 2007. № 4. С. 130-140.

3. Скрипко Т. Інвестиційно-інноваційна активність малого і середнього підприємництва як чинник економічної безпеки держави : монографія. Львів : Ліга-Прес, 2013. 384 с.

4. Державне регулювання процесу інтелектуалізації економіки України : монографія / ред. Т. Васильців, Н. Гунчак, О. Сухай. Львів : Апріорі, 2016. 256 с.

5. Мельник А., Васіна А. Структурна трансформація національної економіки України як чинник модернізації інституційного базису її розвитку. Журнал європейської економіки. 2010. Т. 9 (№ 1). С. 37-58.

6. Федулова Л. Прогнозування інноваційно-технологічного розвитку економіки як складова вибору стратегії виходу з кризи. Економіка і прогнозування. 2009. № 3. С. 5-17.

7. Бужимська К. Деякі складові теоретико-методологічної бази інноваційно-технологічної модернізації. Вісник ЖДТУ. 2009. № 4. С. 202-207.

8. Вешко А. Реіндустріалізація країн Сврозони як передумова промислового ренесансу економіки України. Журнал європейської економіки. 2013. Т. 12. № 2. С. 233-241.

9. Бузмакова М. Реиндустриализация - тенденция мировой экономики. Вестник Нижегородского университета. 2017. № 1 (45). C. 7-17.

10. Васильців Т., Соколова О. Напрями зміцнення економічної безпеки підприємництва України. Науковий вісник НЛТУ Украӥни. 2007. Вип. 17.3. С. 202-206.

11. The World Bank. High-technology exports (\% of manufactured exports). URL: https://data.worldbank.org/indicator/ TX.VAL.TECH.MF.ZS?name_desc=false.

\section{References:}

1. Vasyltsiv, T. and Magas, N. (2014), "Prerequisites of competitiveness of retail enterprises", Scientific Herald of the National Forestry University of Ukraine, no. 24.2, pp. 218-222.

2. Oviechkina, O. and Ivanova, K. (2007), "An overview of methods for assessing the level of innovation potential of economic entities", Ekonomichnyi visnyk Donbasu, no. 4, pp. 130-140.

3. Skrypko, T. (2013), Investytsiino-innovatsiina aktyvnist maloho i serednioho pidpryiemnytstva yak chynnyk ekonomichnoi bezpeky derzhavy [Investment and innovation activity of small and medium-sized enterprises as a factor of economic security of the state], monograph, Liha-Pres, Lviv, Ukraine, $384 \mathrm{p}$.

4. Vasyltsiv, T., Hunchak, N. and Sukhai, O. (ed.) (2016), Derzhavne rehuliuvannia protsesu intelektualizatsii ekonomiky Ukrainy [State regulation of the process of intellectualization of the economy of Ukraine], monograph, Apriori, Lviv, Ukraine, $256 \mathrm{p}$.

5. Melnyk, A. and Vasina, A. (2010), "Structural transformation of the national economy of Ukraine as a factor in modernizing the institutional basis for its development". Zhurnal Yevropeiskoi ekonomiky, vol. 9 (no. 1), pp. 37-58.

6. Fedulova, L. (2009), "Predicting the innovation and technological development of the economy as a component of the choice of a strategy for solving the crisis", Ekonomika ta prohnozuvannia, no. 3, pp. 5-17.

7. Buzhymska, K. (2009), "Some components of the theoretical and methodological basis of innovation and technological modernization". Visnyk ZhDTU, no. 4, pp. 202-207.

8. Veshko, A. (2013), "Re-industrialization of the euro area countries as a prerequisite for the industrial renaissance of the Ukrainian economy". Zhurnal Yevropeiskoi ekonomiky, vol. 12, no. 2, pp. 233-241. 
9. Buzmakova, M. (2017), "Reindustrialization - basis of world economy". Vestnik Nizhegorodskogo universiteta, no. 1 (45), pp. 7-17.

10. Vasyltsiv, T. and Sokolova, O. (2007), "Areas of strengthening economic security of entrepreneurship in Ukraine". Scientific Herald of the National Forestry University of Ukraine, no. 17.3, pp. 202-206.

11. The World Bank. High-technology exports (\% of manufactured exports). URL: https://data.worldbank.org/indicator/ TX.VAL.TECH.MF.ZS?name_desc=false.

Shushkova Yuliia

Ivan Franko National University of Lviv

\section{ANALYZING THE EFFECTIVENESS OF THE STATE POLICY OF SUPPORTING AND STIMULATING TECHNOLOGICAL REFORMS IN UKRAINE}

The goal of the article is to analyze the effectiveness of the state policy of support and stimulation of technological reforms in Ukraine. It was established that the basic tasks of the state technological modernization policy are not fulfilled in Ukraine. In the process of research methods are used: comparative analysis - for comparing the level of development of innovation and technological activities in Ukraine and the countries of the European Union; analysis and synthesis - for the formation of conclusions on the efficiency of the state policy to ensure technological modernization of the economy of Ukraine in terms of functions. With regard to the task of organization and management, it is the lack of central authority and local structures that ensure the formation and implementation of state policy. As to the task of planning, a system of strategic planning of technological modernization of the economy, absent-concrete instruments and mechanisms of regulation, is unreformed. Concerning the task of formation of the right field, the need to review the provisions of the basic normative legal acts regulating innovation and technological activity, in particular towards strengthening of effective instruments of stimulation and support the development of innovative and technological activities. As to the task of becoming an infrastructure, the level of development and weak institutional capacity of infrastructure elements of support and stimulation of the process of technological modernization of the national economy are low. As to the task of ensuring motivation, the weak remains the ability of the financial and credit system to promote innovation and technological development of the economy. The methodological approach to assessing the effectiveness of the state policy of technological modernization of the economy is improved. In contrast to the classical analysis of the method of qualitative analysis with colds of quantitative indicators, providing the consistent verification of functions and implementation of basic tasks of state policy in the analytical sphere is proposed. Consideration and correction of identified shortcomings of the state policy of technological modernization will allow the supreme bodies of public administration to improve the main instruments of state regulation in the field of innovation and technology Economic development.

Key words: technological modernization, functions and tasks, state innovation and technological policy.

JEL classification: 038 . 